\title{
O que ocorreu nos últimos 2000 anos no vale do Peruaçu? Uma análise multidisciplinar para abordar os padrões culturais e suas mudanças entre as populações humanas daquela região
}

Fábio de Oliveira Freitas*

Maria Jacqueline Rodet**

FREITAS, F.O; RODET, M.J. O que ocorreu nos últimos 2000 anos no vale do Peruaçu? Uma análise multidisciplinar para abordar os padrões culturais e suas mudanças entre as populações humanas daquela região. Revista do Museu de Arqueologia e Etnologia, São Paulo, 20: 109-126, 2010.

Resumo: Procurou-se determinar distintas fontes de caracteristicas culturais das populações humanas pré-históricas, que viveram no Vale do Peruaçu Minas Gerais - Brasil, ao longo de seu perfil temporal, desde 10.000 anos atrás, mas principalmente entre o periodo de 2000 e 500 anos atrás, a fim de embasar a construção dos cenários vivenciados no cotidiano daquelas populações. E, a partir da analise das caracteristicas e a evolução deste conjunto de fatores materiais, deixados pelas populações, vislumbrar e intuir parte da cultura e costumes imateriais locais. As análises se basearam em ferramentas da indústria litica; alimentos utilizados, principalmente o milho; sepulturas; estruturas de "armazenamento" de alimentos; e dados próprios e da literatura sobre os sitios arqueológicos da região. Assim, podemos afirmar que houve uma grande mudança cultural na região entre 2000 e 500 anos atrás, questão aprofundada na discussão do artigo.

Palavras-chave: Cultura pré-histórica - Milho - Tradição litica - Dinâmica cultural.

\section{Introdução}

cultura de um povo é composta de elementos diversos, tais como sua lingua, suas formas de expressões artísticas, seu

${ }^{*}$ E) Embrapa Recursos Genéticos e Biotecnologia. $<$ fabiof@cenargen.embrapa.br> ${ }^{(* *)}$ Universidade Federal de Minas Gerais. <jacqueline.rodet@gmail.com> vestuário, seus hábitos alimentares, seus utensilios, sua dimensão imaginária, entre outros (Arantes 1981). Pode-se, ainda, afirmar que a cultura é tudo o que o Homem adiciona à natureza, tudo o que ele constrói (Hamze 2005).

O fato é que a cultura de um povo, préhistórico ou não, apresenta detalhes que são comuns a outras culturas, principalmente no mundo contemporâneo-globalizado. Por outro lado, elas apresentam também elementos 
O que ocorreu nos últimos 2000 anos no vale do Peruaçu? Uma análise multidisciplinar para abordar os padrões culturais e suas mudanças entre as populações humanas daquela região.

Revista do Museu de Arqueologia e Etnologia, São Paulo, 20: 109-126, 2010.

singulares que permitem caracterizá-las, pelo menos em um determinado local e em uma determinada época. Outra caracteristica intrínseca da cultura é seu dinamismo. Ela muda ao longo do tempo, se modifica, seja pela própria evolução interna, seja pelo contato com outros povos, assimilando costumes e reescrevendo os seus próprios ou, em casos mais drásticos, mudando sua própria cultura pela imposição de outra.

Na pré-história, a transformação da tecnologia presente na realização dos instrumentos é um dos elementos que permite, muitas vezes, detectar as mudanças e "identificar" grupos. Outra possibilidade é através das plantas domesticadas. É possivel, pela identificação e caracterização das espécies e variedades domésticas e/ou manejadas no passado, identificar quais plantas e variedades tais grupos pré-históricos utilizavam e a relação dessas com outras regiões e grupos humanos que as utilizavam.

Através das especificidades culturais, podese tentar remontar parte da história dos povos do passado, tentar reconstituir parcialmente seu cotidiano, por onde passaram, quais eram seus territórios, suas tecnologias, quais povos influenciaram ou foram influenciados por seus hábitos alimentares etc.

Deste modo, neste artigo abordaremos alguns aspectos da cultura de populações que habitavam a região do norte do estado de Minas Gerais, mais especificamente, a bacia do rio Peruaçu, afluente da margem esquerda do rio São Francisco, durante o Holoceno recente, aproximadamente 2.000 anos AP (horticultores-ceramistas) até o contato com os neobrasileiros (século XVIII d.C.). Nesta região, os primeiros vestigios de ocupação humana aparecem a partir de 12.000 AP e a horticultura por volta de 2.000 AP.

De modo mais especifico, discutiremos a função dos "cestos" com restos vegetais encontrados enterrados em diversos abrigos da região, comumente chamados de Silos. Apresentaremos, ainda, as indústrias liticas e cerâmicas desse periodo horticultor. Teceremos considerações sobre uma possivel mudança cultural sofrida por volta de $600 \mathrm{AP}$, baseada em evidências de natureza alimentar e da tecnologia presentes nos instrumentos de pedra e de cerâmica.

\section{Apresentação da região}

A região da bacia do rio Peruaçu está situada no extremo norte do estado de Minas Gerais, a 620 km de sua capital, Belo Horizonte, nos municipios de Januária e de Itacarambi (Fig. 1). A área se encontra dentro de um setor de transição entre as florestas xerófilas do tipo caatinga e o cerrado.

O rio nasce sobre os arenitos Urucuia e escorre até a margem esquerda do grande rio São Francisco. Em seu médio curso, durante $17 \mathrm{~km}$, ele penetra no maciço calcário do grupo Bambui, formando um grande cânion repleto de cavernas, abrigos, ressurgências etc. Esta região é importante no contexto arqueológico e geomorfológico do Brasil Central em razão da centena de sítios arqueológicos registrados e de seu imponente relevo cárstico. A região foi sucessivamente ocupada por grupos préhistóricos desde a transição Pleistoceno/ Holoceno, até a colonização portuguesa no século XVIII.

A equipe de arqueologia do Museu de História Natural - UFMG (MHN-UFMG) se interessou pelo setor nos anos 1970, com a arqueóloga A. Laming-Emperaire, e iniciou seus trabalhos na região no início dos anos 1980 (Prous 1991a). Há quase 30 anos, o Setor de Arqueologia desenvolve uma pesquisa pluridisciplinar na região, escavando e estudando sitios de abrigo e a céu aberto. Os abrigos calcários, por serem secos e de solo básico, são um excelente conservador para a matéria orgânica. Por esse motivo, inicialmente, os abrigos tiveram prioridade nos estudos realizados. As escavações permitiram exumar vestigios em excelente estado de conservação, tais como: sepultamento naturalmente semi-mumificado, restos vegetais secos em uma excelente conservação das partes delicadas (folhas, haste, flor), além de vestigios cerâmicos e liticos. Nas paredes dos abrigos e entradas de grutas, milhares de pinturas rupestres e figuras picoteadas foram calcadas e/ ou fotografadas. 


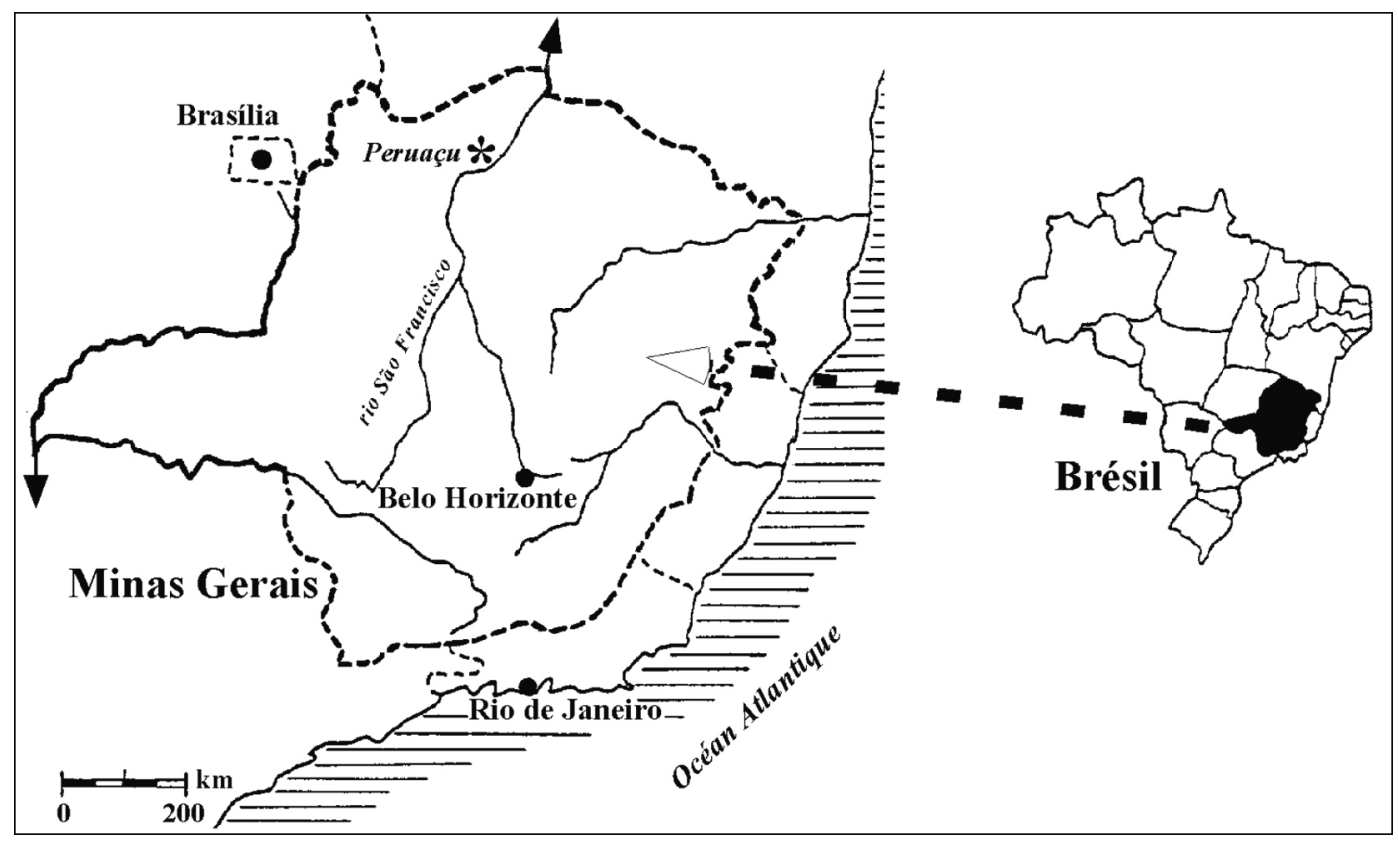

Fig. 1. Mapa de localização.

Os silos, assunto deste artigo, estão presentes na parte superior da estratigrafia dos abrigos, entre as camadas II e o contato I-0, muito bem conservados, aparecendo entre os niveis que contêm os sepultamentos, nunca ao mesmo tempo que os mesmos. Vários sítios arqueológicos estudados no setor apresentaram silos: Lapa do Boquete (sitio referência para o Brasil Central), Lapa da Hora, Lapa do Caboclo, Abrigo do Malhador e Abrigo do Tikão (não exumado). Os silos exumados foram em parte analisados, os outros encontram-se acomodados no MHN-UFMG e já foram alvo de diversas publicações(Prous 1994 e Relatório FNMA 1997; Resende 1994; Resende e Cardoso 1996; 1997; Freitas 2001, 2002, 2003, entre outros).

\section{Os "silos"}

Mesmo tendo sido a presença humana detectada nos abrigos do norte do estado desde a passagem Pleistoceno/Holoceno, $12.000 \mathrm{AP}$ (Prous 1991 a,b; Prous et al. 1992; Fogaça 2000, 2001; Rodet 2006, entre outros), os "cestos" são encontradas somente nos periodos recentes, momento em que aparecem a cerâmica e a horticultura: datações confirmam idades que variam entre 1.500 até $570 \mathrm{AP}$, onde diversas espécies vegetais cultivadas ou coletadas foram ali depositadas(Junqueira e Malta 1981/1982; Prous 1991 a,b; Cardoso e Resende 1992, 2008, entre outros). Os cestos são em geral de pequenas dimensões, globalmente de 18 a 40 $\mathrm{cm}$ de espessura, mas podem chegar a dimensões próximas de $1 \times 1 \mathrm{~m}$, como é o caso daquele exumado na lapa da Hora.

Trata-se de estruturas que variam em morfologia e tamanho, realizadas em madeira e folhas de palmeiras e de milho, algumas vezes com divisões interiores, enterradas nos abrigos e aparentemente, recobertos por cinzas de fogueiras (Fig. 2). O conteúdo dos cestos é principalmente de vegetais - domesticados e silvestres - (Fig. 3), mas há também a presença, mesmo que pouco frequente, de certos elementos que não são comestiveis, tais como plumas, peças liticas, conchas e contas de colares. Os vegetais, em sua maior parte, são: sabugos de milho (Zea mays mays), alguns inteiros com grãos e palha, mas a maioria sendo fragmentos 
O que ocorreu nos últimos 2000 anos no vale do Peruaçu? Uma análise multidisciplinar para abordar os padrões culturais e suas mudanças entre as populações humanas daquela região.

Revista do Museu de Arqueologia e Etnologia, São Paulo, 20: 109-126, 2010.

do sabugo sem grãos; fragmentos de coquinho Guariroba (Syagrus oleracea), esta sendo a espécie mais abundante entre as plantas não cultivadas; feijão (Phaseolus sp); mandioca (Manihot esculenta); algodão (Gossypium); e provavelmente amostras de tabaco (Nicotiana tabacum), amendoim (Arachis hypogea) e pimenta (Capsicum), entre outras espécies.

As morfologias dessas estruturas foram recentemente descritas de uma maneira geral e podem ser assim sintetizadas(Cardoso e Resende 2008): i) afunilados - profundos, largos na superfície e estreitos na base; ii) cilindricos - profundos, apresentando paredes verticais, estreitas da superficie à base; iii)

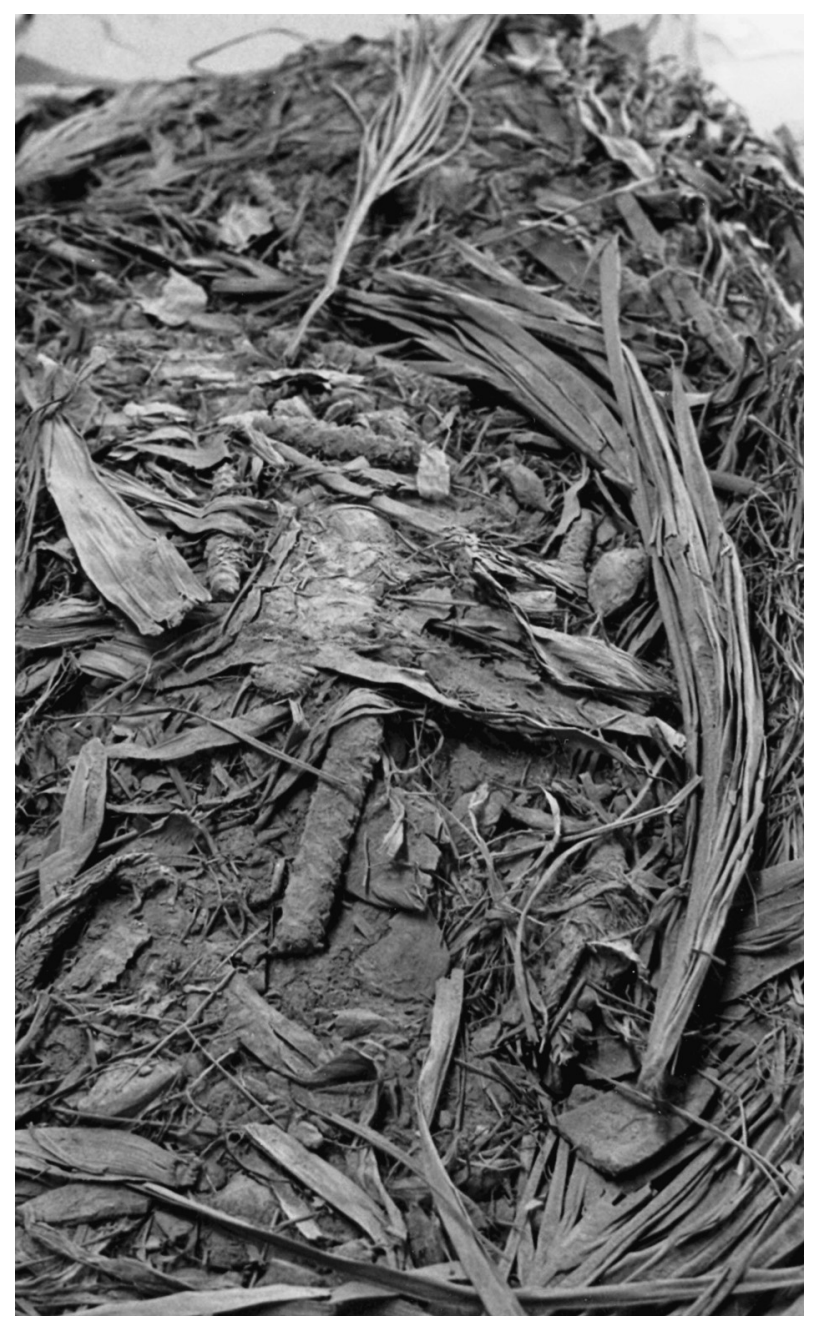

Fig. 2. Foto de detalhe de um silo. achatados - pouco profundos, com bordas largas na superficie. As estruturas foram ainda classificadas pela morfologia das bordas: circulares, ovais e irregulares. Estes últimos, muito provavelmente, devido às perturbações, recentes ou pré-históricas. Vale ressaltar que, na lapa do Boquete, existem pelo menos três niveis de silos que se sobrepõem, sendo que alguns perfuram completamente o solo arqueológico, misturando vários niveis estratigráficos.

Os grupos coletores-horticultoresceramistas que frequentaram a região perfuraram os solos dos abrigos para instalar esses cestos cheios de vegetais: aproximadamente 30 estruturas desse tipo e os negativos de muitas outras foram identificados na lapa do Boquete. Como anunciado anteriormente, a mais antiga delas está datada de 1.500 AP, enquanto a mais recente de 570 AP. Isto indica uma utilização que perdurou quase 1.000 anos para esse tipo de estrutura. No entanto, se dividirmos simplesmente os 30 silos por 1.000 anos, obteremos 0,03 silo por ano, o que é uma média muito baixa. Mesmo se dobrarmos a quantidade, pensando que os negativos podem se referir a 30 outros, ainda assim o número é muito baixo. $\mathrm{Ou}$ seja, esta quantidade, está longe de ser uma forma de estocagem anual.

Ainda, devido à perda natural do poder germinativo das sementes e propágulos, as partes reprodutivas ali armazenadas dificilmente conseguiam manter por muito tempo sua capacidade reprodutiva a ponto de poder ser utilizada em uma nova roça agrícola depois de um ou dois anos após ter sido enterrada. Deve-se levar em conta ainda que outros abrigos também têm silos e que somente no futuro, quando houver um maior número de escavações no setor, poderemos ter uma idéia mais aproximada da realidade desses grupos.

Outro elemento que nos ajuda a entender esse periodo e distingui-lo dos anteriores é a tecnologia presente nas indústrias líticas e cerâmicas. 


\begin{tabular}{|c|c|c|c|}
\hline \multicolumn{4}{|c|}{ Plantas Coletadas } \\
\hline Nome popular & Nome científico & Família & Parte vegetal \\
\hline Guariroba & Syagrus oleracea M. & Palmae & amêndoa, peciolo ou folha \\
\hline Cansanção & Cnidoscolus sp & Euphorbiaceae & endocarpo ou tegument \\
\hline oUmbu' & Spondias tuberosa & Anacardiacae & endocarpo \\
\hline Mutamba & Guazuma ulmifolia lamm. & Sterculiceae & fruto \\
\hline Jatoba & Hymenaea sp. & Leguminosae & grão ou legume \\
\hline Pequi & Caryocar brasiliense camb. & Caryocaraceae & fruto \\
\hline Chicha & Sterculia sp. & Sterculiceae & grão \\
\hline Pitomba & Tasilia esculenta radlk & Sterculiceae & grão \\
\hline Maracujá & Passiflora sp. & Passifloraceae & grão \\
\hline Cagaita & Eugenia dysenterica DC. & Myrtaceae & grão \\
\hline Araticum & Annona sp. & Ananoceae & grão \\
\hline Murici & Bursonima sp. & Malpighiaceae & endocarpo \\
\hline Angico & Piptadenia sp. & Leguminosae & casca \\
\hline Licuri & Syagrus coronata $\mathrm{M}$. & Palmae & amêndoa \\
\hline Erva de pássaro & Struthanthus sp. & Loranthaceae & fruto \\
\hline Jurubeba & Solanun sp. & Solanaceae & fruto \\
\hline Tamboril & Enterolobium sp. & Leguminosae & grão,fruto \\
\hline Cajá & Spondias lutea $l$. & Anacardiaceae & endocarpo \\
\hline Fava Santo Inácio & Fevillea trilobata $l$. & Cucurbitaceae & grão \\
\hline Pente de macaco & Scleria sp. & Bignoneaceae & grão, fruto \\
\hline \multicolumn{4}{|c|}{ Plantas Domesticadas } \\
\hline Milho & Zea mays $l$. & Gramineae & espiga, grão, palha \\
\hline Cabaça & Lagenaria vulgaris ser. & Cucurbitaceae & grão, fruto \\
\hline Algodão & Gossypium sp. & Malvaceae & grão, fruto \\
\hline Urucum & Bixa orellana $l$. & Bixineae & cápsula, grão \\
\hline Mandioca & Manihot sp. & Euphorbiaceae & raiz, fruto \\
\hline Feijão & Phanseolus sp. & Papilionaceae & grão \\
\hline
\end{tabular}

Fig. 3. Lista de vegetais identificados nos silos do sítio arqueológico lapa do Boquete: a maioria dos vestigios encontra-se em excelente estado de conservação. Os vegetais domesticados demonstram a presença de grupos horticultores [de acordo com Resende e Cardoso 1997, modificado por M.J. Rodet 2006].

\section{As indústrias cerâmicas e líticas do período horticultor}

Se até por volta de $2.000 \mathrm{AP}$ não havia nenhum vestigio da presença da cerâmica no norte do estado, a partir desse momento aparecem fragmentos de uma cerâmica denominada Una (Fig. 4). Na camada II da lapa do Boquete, 240 fragmentos cerâmicos foram exumados das escavações.

De acordo com P. Jobim (1997), a cerâmica encontrada em estratigrafia nos abrigos do Peruaçu é confeccionada por roletes, sem decoração, apresentando paredes finas $(0,4 \mathrm{e}$
$0,8 \mathrm{~cm}$ ) e pasta pouco oxidada. $O$ tratamento de superfície é o polimento, alisado grosseiramente e escurecido por fumaça. Às vezes esse tratamento pode ser observado também na parte interna dos fragmentos, onde domina a cor amarronzada. Existe, porém, uma variação no antiplástico que compõe a pasta: quanto mais antigos são os niveis, maior é a quantidade de areia em detrimento da quantidade de carvão utilizado. No que se refere às formas das vasilhas, essas são frequentemente fechadas e globulares (5 a $13 \mathrm{~cm}$ de abertura) sobre uma base. Os lábios são arredondados, mais raramente pontiagudos. Excepcionalmente é 

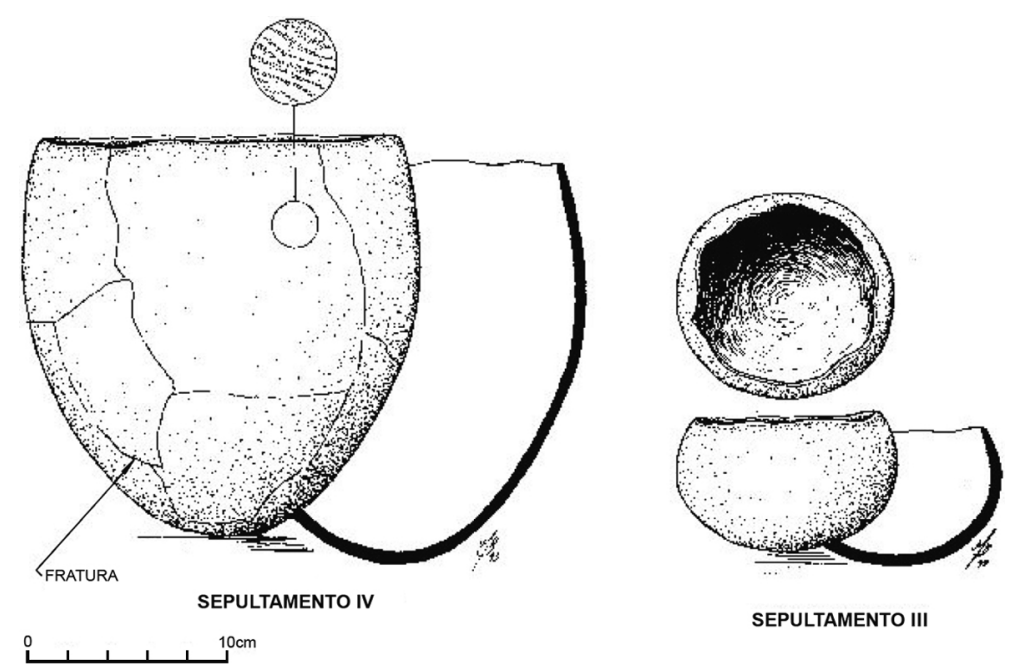

Fig. 4. A cerâmica Una: esses elementos acompanhavam os sepultamentos II e IV do abrigo do Boquete [Desenho M. Brito].

possivel observar bordos incisos ou ondulados, mas jamais pintados (Prous1994b).

As indústrias líticas desse grande periodo denominado Holoceno recente são diferentes daquelas dos periodos anteriores (Holocenos médio e antigo). A sequência estratigráfica desta época, na lapa do Boquete, é perturbada, devido ao grande número de cestos e de sepultamento. No entanto, vários setores não foram atingidos por essas perfurações e são principalmente eles que serviram de base para a caracterização das indústrias.

A partir do estudo de alguns sítios arqueológicos do norte do estado podem-se observar as transformações no registro arqueológico dos niveis superiores. Os sitios que serviram de referência para o estudo do periodo: Boquete interno (niveis II, I, $\varnothing-1.600 \mathrm{AP}$ a $570 \mathrm{AP}$ ), Lapa do Índio (nivel I - 2.240 AP), Terra Brava (nivel II), Rusinho (nivel Ø inf. - 1.050 AP) e abrigo do Malhador. Os dois últimos mil anos correspondem a uma grande mudança na ocupação da bacia, não somente pela "chegada" de plantas domesticadas ou pela "aparição" da cerâmica, mas também no plano lito-tecnológico. Se até então havia uma produção de grandes objetos, principalmente unifaciais, sobre grandes lascas de silexito, quartzito e arenito silicificado, neste periodo há uma ruptura da produção litica. O conjunto lítico fornece lascas realizadas principalmente em silexito de dimensão pequena a média, pouco normalizadas, que são depois transformadas em instrumentos muitos simples, pouco transformados ou utilizadas brutas de debitagem, ou seja, sem transformação após a retirada das mesmas do núcleo (Fig. 5). Outra modificação nesse plano é a utilização considerável do calcário e do quartzo. Ressalta-se que, paralelamente, um pequeno grupo de lascas produzidas principalmente em arenito, quartzo hialino e calcário, demonstra uma elaboração particular. Estas peças, certamente fazem parte de uma cadeia operatória mais elaborada, de instrumentos unifaciais e mais raramente bifaciais, mas certamente não são os vestigios mais abundantes do periodo.

Em sintese, podemos afirmar que na indústria litica, a situação muda se comparada ao periodo anterior - Holoceno médio. A taxa de acidente de lascamento é notavelmente mais considerável (camada I: os acidentes atingem até $58 \%$ das peças), na medida em que a abrasão do talão se faz cada vez mais rara. Notamos principalmente dois subconjuntos líticos distintos (Fig. 6):

1) grupo de lascas mais numeroso, em geral resultante de uma debitage pouco elaborada: produtos não estereotipados, sem abrasão, acidentados. Os 
talões são principalmente lisos, mas apareceram alguns talões diedros, esses últimos possiveis indicadores de lascamento de peças bifaciais.

2) pequeno grupo de lascas de façonagem, mais elaboradas, frequentemente abrasadas mas não o suficiente para impedir acidentes do tipo refletido, produzidas por percussão direta dura no arenito, no quartzo, no calcário e, mais raramente, no silexito. Esse grupo mostra uma procura por produtos mais caracteristicos, tais como os unifaciais e os bifaciais (dois exemplares no nivel II), o que concorda com o pequeno aumento dos talões diedros, correspondentes a uma produção de instrumentos bifaciais (Fig. 5). Nota-se, ainda, a presença de lascas retiradas por percussão direta macia, provavelmente percutor de madeira, indicando um conhecimento tecnológico mais meticuloso.

Os vestigios presentes nas camadas arqueológicas demonstram que a ocupação dos abrigos mudou radicalmente nesse periodo (horticultor-ceramista), não só pelos elementos já descritos, mas também por uma produção mais importante de pigmentos, principalmente vermelho e amarelo, que estão relacionados às fossas sepulcrais e também às estruturas de combustão, principalmente no abrigo do Malhador. A tecnologia presente nas indústrias liticas assim como as escolhas das rochas e minerais que serviram de suporte para a confecção de instrumentos muda no início do periodo. Essa modificação vai se afirmar cada vez mais ao longo dos anos, até o Contato.

Os grupos humanos parecem ter se sedentarizado. Eles passam a utilizar plantas cultivadas e produzir cerâmica. Os abrigos tiveram o apogeu de sua vocação cerimonial (enterramentos, pinturas e oferendas). O instrumental litico, menos elaborado, demonstra o lugar secundário que essa tecnologia tomou, seguramente em benefício de outras. É a grande passagem dos caçadores-coletores para os horticultores-ceramistas.
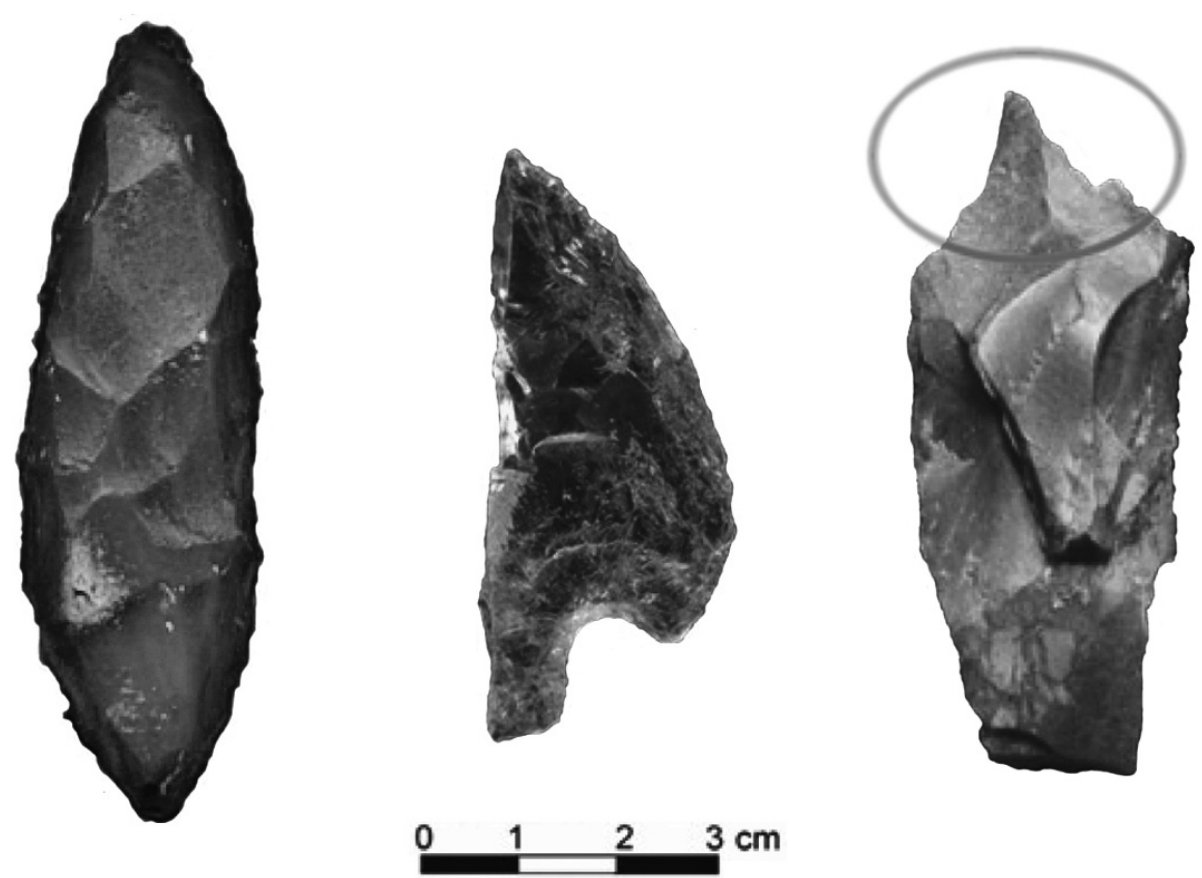

Fig. 5. Instrumentos elaborados e simples: da esquerda para direita, unifacial retocado, ponta de projétil bifacial e instrumento simples, utilizado como furador. 


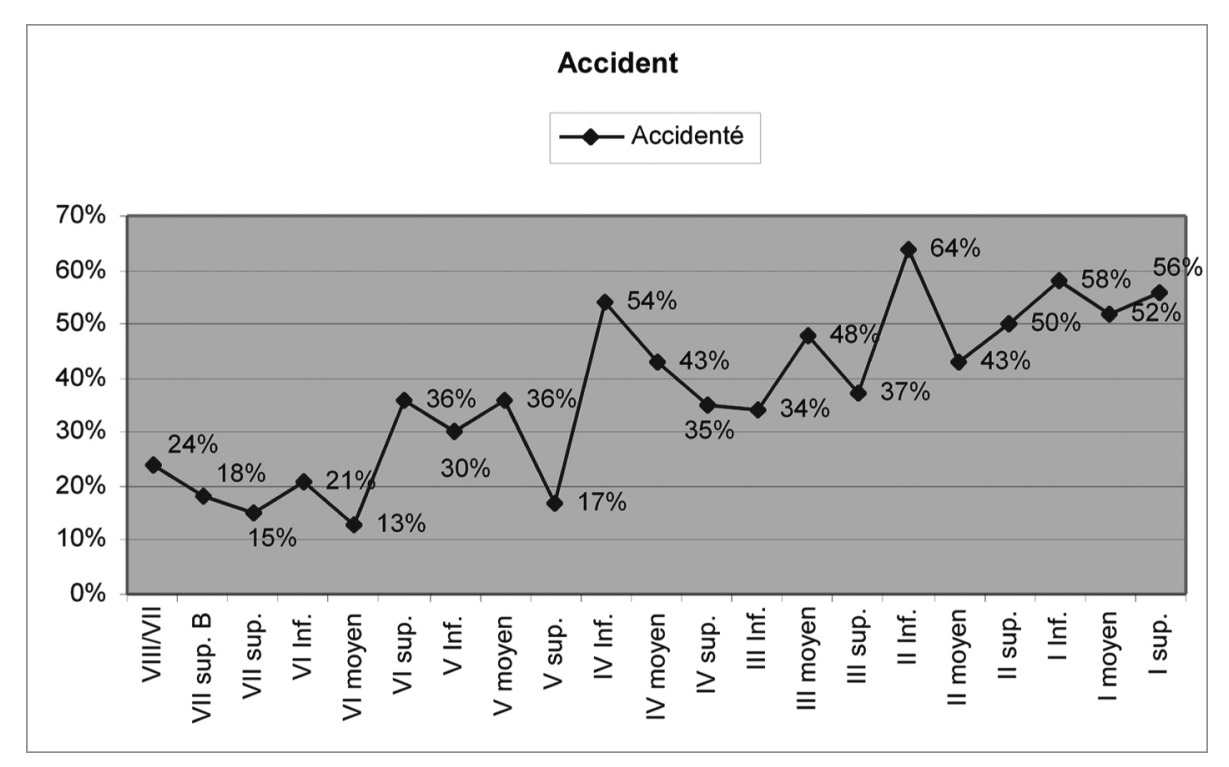

Fig. 6. Acidentes presentes nos vestígios liticos da Lapa do Boquete: em geral, os acidentes aumentam do início ao fim da ocupação, com alguns momentos particulares, como por exemplo na camada $\mathrm{V}$, quando observa-se uma queda importante no nivel de acidentes. Trata-se de refletidos, mais raramente de fraturas em Siret, de algumas raras ultrapassagens e raras quebras em lingüeta [figura retirada de MJRodet 2006].

\section{Discussão}

É interessante notar que somente a partir do periodo em que as plantas domesticadas chegam ao setor estudado os grupos desta região começam a ter o hábito de construir e a enterrar essas cestas. Este costume se manteve por mais de 1.000 anos subsequentes. A questão que nos colocamos é a de saber se essas estruturas seriam para armazenar alimentos para consumo, ou para armazenamento de propágulos, a serem usados em plantios posteriores, como forma de conservar os materiais utilizados tradicionalmente; ou ainda poderiam ter sido utilizados apenas para fins cerimoniais, como oferenda, por exemplo.

Se a função dessas estruturas fosse de armazenamento para uso posterior, tanto para alimentação direta ou para plantio, os materiais estocados deveriam conter as partes comestiveis e/ou partes reprodutivas (sementes, manivas, entre outros).

No entanto, quando analisamos as amostras vegetais encontradas nesses cestos, observou-se para o milho - espécie domesticada mais abundante -, que na maior parte dos casos, as amostras dessa espécie são compostas apenas por sabugo, sem os grãos. Poderia haver a possibilidade de os grãos não terem se conservado com o tempo, mas esta hipótese é descartada pelo fato de existirem amostras de mais de 1.000 anos de idade com sabugos completos, como mostra a Fig. 7, além da presença de diversos grãos de milho soltos em diferentes silos, com idades distintas, desde 1.000 até 450 anos atrás.

De fato, aparentemente, a maior parte das amostras de milho encontradas nos silos foi depositada já sem as sementes. Neste caso, esses sabugos não teriam uma função alimentar posterior, e também não seriam para conservação de partes reprodutivas para plantio futuro.

Outro exemplo é em relação à mandioca. Para esta espécie, a parte usada como alimento é a "raiz" da planta, rica em amido. Já a parte utilizada para plantio, é conhecida como maniva, que consiste em um pedaço da parte aérea da planta, o caule. Nas amostras encontradas nos silos, só foram observadas as raizes de mandioca, e não as manivas. Ainda, as raizes 


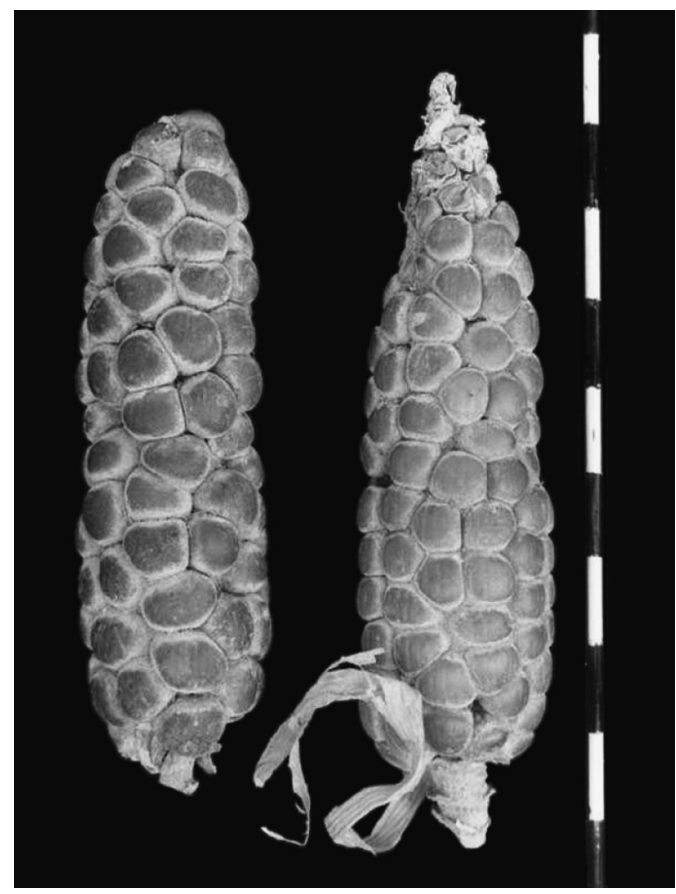

Fig. 7. Amostras de espigas de milho: encontradas em um silo no sítio arqueológico da Lapa do Boquete, com idade datada em 1000 A.P.

encontradas eram muito pequenas, exatamente aquelas comumente rejeitadas quando da colheita na roça. Adicionalmente, uma dessas amostras, com idade de $760 \mathrm{AP}$, é composta apenas de uma parte da raiz de (aproximadamente $3 \mathrm{~cm}$ ), referente à ponta de uma outrora raiz maior. Ao analisar este fragmento em lupa de aumento (20X), vemos que o mesmo não foi quebrado, mas sim "gasto", como quando ralado - técnica comum no preparo da mandioca para consumo entre populações tradicionais até hoje.

Se as populações daquela época depositaram um pedaço já ralado, que não poderia ser usado nem para alimentação nem para plantio, talvez a intenção fosse apenas a de depositar uma parte que representasse a planta, como forma de lembrança da mesma, em uma possivel oferenda.

As análises das amostras de coquinho guariroba, a espécie silvestre mais abundante nos silos, demonstram que os mesmos foram previamente quebrados, antes do depósito nos silos. Dentre as amostras estudadas não foram encontrados coquinhos inteiros. Esta espécie tem uma casca extremamente dura, assim supõe-se que algumas amostras poderiam estar conservadas intactas, caso os mesmos tivessem sido depositados integralmente, até porque outras amostras, de material mais frágil, se preservaram ao longo do tempo, no mesmo local.

Aparentemente, os pré-históricos quebraram estes coquinhos, retiraram suas amêndoas e só depositaram as cascas. Portanto, este material também não poderia servir como alimento, ou como fonte propagadora, reforçando a idéia de que o silo tinha uma função cerimonial.

Por outro lado, outros estudos recentes levantam uma hipótese de que, durante o Holoceno médio e recente, os abrigos calcários do norte do estado tenham tido uma "vocação cerimonial”. Neste periodo, esses locais teriam sido usados como espaços para realizar certos ritos, tais como sepultamentos, oferendas de vegetais, fogueiras exclusivamente com pigmentos e pinturas rupestres (Rodet 2006, 2009; Rodet et al. 2008).

De acordo com Rodet (2006), as ocupações dos sitios demonstram uma diferenciação em sua utilização ao longo do tempo. Esses teriam evoluído de um status de simples "sítios de passagem” e paradas rápidas a um espaço de vocação ritual. Nos primeiros momentos da ocupação - passagem Pleistoceno-Holoceno, 12.000-10.000 AP e Holoceno antigo, 10.0008.000 AP - os abrigos eram utilizados de maneira discreta como indicam algumas fogueiras com poucos restos de animais e de vegetais, assim como alguns utensilios fragmentados abandonados dentro das mesmas. Os vestígios líticos encontrados nos abrigos escavados consistem em restos de façonagem e retoque, em grande parte queimados, sem que saibamos bem porquê. Durante todo esse periodo as fogueiras são sempre representativas de uma passagem rápida dos grupos. No sítio da Lapa do Boquete, a presença de certos frutos sazonais (pequi, Caryocar brasiliense camb.) enfatiza uma frequentação durante um periodo especifico. 
O que ocorreu nos últimos 2000 anos no vale do Peruaçu? Uma análise multidisciplinar para abordar os padrões culturais e suas mudanças entre as populações humanas daquela região.

Revista do Museu de Arqueologia e Etnologia, São Paulo, 20: 109-126, 2010.

As modificações mais importantes na maneira de ocupar os abrigos acontecem em torno de $9.000 \mathrm{AP}$, quando foi encontrado o primeiro sinal de uma representação gráfica entalhada sobre um bloco calcário, em seguida, em torno de $8.000 \mathrm{AP}$, quando as fogueiras contêm não somente restos alimentares, mas também manchas de pigmentos. No abrigo do Malhador, algumas fogueiras não contêm restos alimentares, mas em suas periferias aparecem manchas de pigmentos vermelhos e amarelos, o que aponta para uma utilização especifica cada vez mais afirmada.

Essas modificações persistem e, por volta de 7.000 AP, aparecem os primeiros sepultamentos. A relação fogo-pigmento persiste e encontramos também esses pigmentos dentro dos sepultamentos. Durante os periodos seguintes (4.000-700 AP), a vocação cerimonial ou simbólica desses abrigos parece estabelecida. Além dos elementos já citados, esses espaços são utilizados, a partir do uso de plantas cultivadas, como local de estocagem dos cestos com vegetais que aí são enterrados. Em alguns deles, aparecem vários sepultamentos. Os abrigos estão cobertos de pinturas, que podem chegar até $10 \mathrm{~m}$ do solo atual (lapa dos Desenhos). A única datação direta dessas pinturas as situa, pelo menos por uma parte, próxima de 3.000 AP (Tradição São Francisco, abrigo do Veado).

Enfim, em superfície (últimos ocupantes pré-históricos) nota-se uma nova modificação nesta ocupação. Se até então a indústria lítica estava representada principalmente pelas fases finais de confecção de instrumentos - façonagem e retoque - neste momento, os utensilios tornam-se numerosos, em alguns abrigos e nos sítios a céu aberto como um todo.

A descoberta de diversos sepultamentos humanos na Lapa do Boquete corrobora a hipótese de que os sítios da região poderiam ter um aspecto mais voltado para fins cerimoniais. Esses sepultamentos aparecem em dois momentos: o primeiro, em torno de 7.000 AP e, o segundo, em periodo mais recente, na época dos horticultores-ceramistas locais, por volta de $810 \pm 70$ AP (Rodet 2006), que coincide com o período dos silos. É interessante notar que nos dois momentos em que os abrigos foram utilizados como local de sepultamento nota-se que aqueles individuos encontrados na lapa do Boquete são homens adultos e crianças (poderiam ser meninos?), enquanto no abrigo do Malhador (distante aproximadamente $4 \mathrm{~km}$, em linha reta), só foram exumados, até agora, sepultamentos com ossadas de mulheres adultas e de crianças (poderiam ser meninas?). Enquanto no primeiro sítio os sepultamentos são suntuosos, com presença de cerâmica, capa em fibra envolvendo o morto, pigmento, quebra-coco, cabaças, lâminas de machado polidas, bolas de própolis etc., no segundo encontramos um acompanhamento mais "simples", pigmentos, fragmento de uma cabaça, fibras vegetais que serviram para envolver o corpo, restos vegetais de uma possivel cobertura do corpo, esqueleto de cobra. Ou seja, existe uma nítida diferença entre os acompanhamentos presentes nos sepultamentos dos dois abrigos. É claro que existe a possibilidade de uma tafonomia diferenciada nos dois sitios. Mal conservados, os objetos delicados tais como fibras ou cascas de árvores, podem ter desaparecido. No entanto, a diferença continua evidente, pois não foram encontradas cerâmicas ou lâminas de machado, por exemplo, nos enterramentos do Malhador. De fato, os dois abrigos são morfologicamente muito diferentes, enquanto o primeiro é pequeno e está na entrada de um antigo poljé, no centro do carste; o segundo está na saida do cânion e é um grande abrigo de aproximadamente $100 \mathrm{~m}$ de desenvolvimento lateral, bastante aberto.

Vale lembrar que a área escavada do abrigo do Malhador $\left(9 \mathrm{~m}^{2}\right)$ pode não ser representativa do sítio, ou seja, é possivel, por exemplo, que existam outros sepultamentos e que os mesmos sejam masculinos. Já as escavações da Lapa do Boquete são mais representativas, pois foram escavados $27 \mathrm{~m}^{2}$ da área abrigada (Rodet 2006).

Caso nossas observações estejam certas, esta distinção de locais de sepultamento por gênero demonstra certos padrões de escolhas dessas populações. Os dois sítios encontram-se em situação geomorfológica diferente: enquanto o Boquete, pequeno setor abrigado, entrada 
de uma gruta, encontra-se no centro do carste, o Malhador, grande abrigo, está na saída do cânion. Esses aspectos denotam não só conhecimento da região, mas também escolhas especificas dentro de um quadro paisagistico.

Nota-se ainda, que no local onde foram enterrados os homens, há um número maior de silos, assim como potes cerâmicos acompanhando os sepultamentos e no das mulheres não. Esta diferenciação estaria ligada à função de cada gênero na aquisição e preparo do alimento? Aparentemente havia uma especialização de ritos entre os gêneros e os sítios.

Outro ponto que remete a uma reflexão é o fato de que na época dos silos, as populações já dispunham de cerâmica. Para fins de armazenamento de gêneros alimentícios, seria muito mais fácil e seguro conservar os alimentos em recipientes de cerâmica do que em cestas de palha, principalmente enterradas, como é o caso. A cerâmica diminui a chance de o material ser atacado por roedores, por exemplo, fato que é percebido em algumas amostras, e também diminuiria o contato com a terra, que seria indesejado se o material fosse servir como alimento, posteriormente. Como não moravam nos abrigos, seria então dificil pensar em armazenar longe da habitação.

Por último, existe o fato de que antigamente, assim como hoje, produzir alimento é um trabalho muito difícil (preparar o terreno, plantar, manter, colher...), além de ser uma tarefa arriscada (intempéries do clima, pragas, doenças, ataque de inimigos...). Dificilmente, as populações conseguiriam produzir excedentes em grandes volumes. De modo geral, muito provavelmente, eles mantinham um mínimo para a próxima safra e consumiam o resto. Esta é inclusive a cultura do Índio. Eles não se preocupam em guardar. Se caçarem um animal, por exemplo, faz-se um grande banquete e come-se tudo, não se importando se vai ter caça amanhã, comumente visto, por exemplo, entre os as tribos do tronco linguístico Gê. Deste modo, é dificil pensar que aquelas populações conseguissem produzir um volume de alimentos muito grande, que pudessem armazenar e depois não utilizar. No entanto, a ideia de tratar-se de um ritual se enquadra melhor nos vestigios encontrados, já que a "oferenda", de modo geral, apenas representa o alimento, sendo que a parte realmente usada para consumo já foi utilizada (espiga de milho sem grãos, pedaço de raiz de mandioca, fruto de coquinho quebrado...).

Esses locais, as entradas de grutas, os abrigos, devem ter tido uma função no imaginário dos grupos. Por exemplo, na Europa, as grutas são os lugares sagrados. No Peruaçu, os pré-históricos não entraram nas grutas (ou pelo menos não deixaram vestígios), mas os abrigos são justamente "as portas" de entrada deste universo subterrâneo. Geomorfologicamente, o abrigo é um "acidente" que divide o espaço, a paisagem: a gruta, local obscuro e desconhecido e o exterior, local cheio de verde e de vida...

\section{Vestígios de mudança cultural}

O segundo ponto que abordaremos neste artigo é sobre os indícios de mudança na cultura daqueles grupos horticultores, em um momento específico da história da ocupação da região - por volta de $600 \mathrm{AP}$-, seja pela chegada de novas populações humanas no local, seja pelo contato das que ali habitavam com outras.

Um forte indício de mudança na cultura da região se refere às espécies cultivadas, principalmente o milho, que, aparentemente, era a planta cultivada de maior importância local, haja vista a sua grande abundância nos silos.

Em um trabalho recente, pesquisadores extrairam material genético de diversas amostras arqueológicas de milho oriundas de abrigos da região e compararam com amostras arqueológicas da região andina, além de diversas amostras da planta oriundas de populações tradicionais e indigenas, desde o sul dos Estados Unidos até o Paraguai (Freitas 2001, 2002; Freitas et al. 2003). Como resultado, os pesquisadores encontraram três grandes grupos/padrões genéticos para o milho. No caso da América do Sul, o primeiro grupo se localiza na região andina, o segundo, mais amplo, na região das terras baixas e o terceiro, 
mais restrito, está inscrito na área de abrangência do segundo e aparece mais ao longo da região leste do Brasil (Fig. 8). Segundo os autores, esses dados sugerem a entrada/difusão de tipos distintos de milho oriundos de levas migratórias ou de contato entre populações humanas, ao longo da América do Sul, a partir da região de origem dessa espécie, o México.

No caso dos abrigos do Peruaçu, oito amostras de milho, de três sítios foram estudadas geneticamente, provenientes dos seguintes sítios arqueológicos: Lapa do Boquete, Lapa da Hora e Lapa do Caboclo, com idades que variavam entre 1.000 e 500 AP. Nas amostras, foram identificados os padrões genéticos dos dois grupos ligados à região das terras baixas, entretanto, enquanto o grupo genético tipo 2 aparece em todos os três sitios e desde as amostras mais remotas até as mais recentes $(1.000$ a $500 \mathrm{AP})$, o tipo genético 3, ao contrário, só é encontrado na lapa do Boquete e somente na amostra mais recente (500 AP).

Segundo os autores, a presença do terceiro padrão somente em uma época mais recente e somente em um sítio, aliada ao fato de o padrão genético possuir uma distribuição mais restrita, em termos de América do Sul, sugere que este terceiro grupo foi difundido de forma independente, menos abrangente e mais recentemente.

Ressalta-se que a região abrangida pelo terceiro grupo genético do milho e o periodo no qual ele aparece no Peruaçu, em parte, foram integrados na chamada expansão Tupi, a qual disseminou costumes e fez com que ocorressem grandes migrações de populações indigenas, no passado, o que fez certamente com que diversos grupos humanos entrassem em contato, muitas vezes de forma conflituosa, causando difusão/aquisição de bens e de costumes.

Outra fonte de dados que corrobora a existência de mudanças na cultura dos grupos nesse periodo se refere à indústria litica local. No conjunto, as indústrias liticas apresentam a produção "clássica", frequentemente observada no Peruaçu, ou seja, uma indústria litica simples, na qual os suportes são pouco transformados, com núcleos pouco organizados tendendo, em fim de exploração, a uma forma globulosa. No entanto, algumas novidades tecnológicas podem ser observadas para os últimos frequentadores da bacia, em dois momentos distintos:

- o mais antigo - nivel $\varnothing / \mathrm{I}$, subsuperfície - pela presença de lâminas de machado polidas, de morfologia retangular, produzidas em anfibolito (sepultamento IV Lapa do Boquete, 560+/-40 Beta 215193) e pelo aumento do número de lascas com talões diedros anunciando uma produção mais intensa de peças bifaciais. Também a matéria prima utilizada para lascamento é mais diversificada que nos periodos anteriores - arenitos variados, jaspe, calcedônia, silexitos variados, quartzo hialino, calcário. $\mathrm{O}$ aumento do número de lascas retiradas de seixos de rio é marcante. A cerâmica é Una;

- o mais recente - nivel $\varnothing$, superfície - aparecem, em superfície, os grandes utensilios unifaciais de morfologia plano-convexa, utensilios bifaciais realizados sobre lascas ou sobre seixos "machados" lascados - algumas pontas bifaciais (sitios Tronqueiras e Minará). Surge ainda, em superfície, dentro de alguns abrigos e em sítios a céu aberto, um novo tipo de cerâmica, pintada, a cerâmica Tupi. As lâminas de machado polidas são numerosas, em geral alongadas, morfologicamente diferentes das anteriores, uma delas em arenito silicificado.

Esse conjunto de elementos permite sugerir que certas produções desse periodo são originais, pois, além das cadeias operatórias já existentes - utensilios unifaciais, utensilios simples, cerâmica Una etc. -, observa-se: i) a diversificação das lâminas de machado polidas (morfologia e matériaprima); ii) a aparição de um novo tipo de cerâmica, a Tupi - coexistindo com a antiga e iii) a realização de machados lascados bifacialmente, alongados e espessos (Fig. 9). No abrigo do Malhador, as últimas fogueiras 


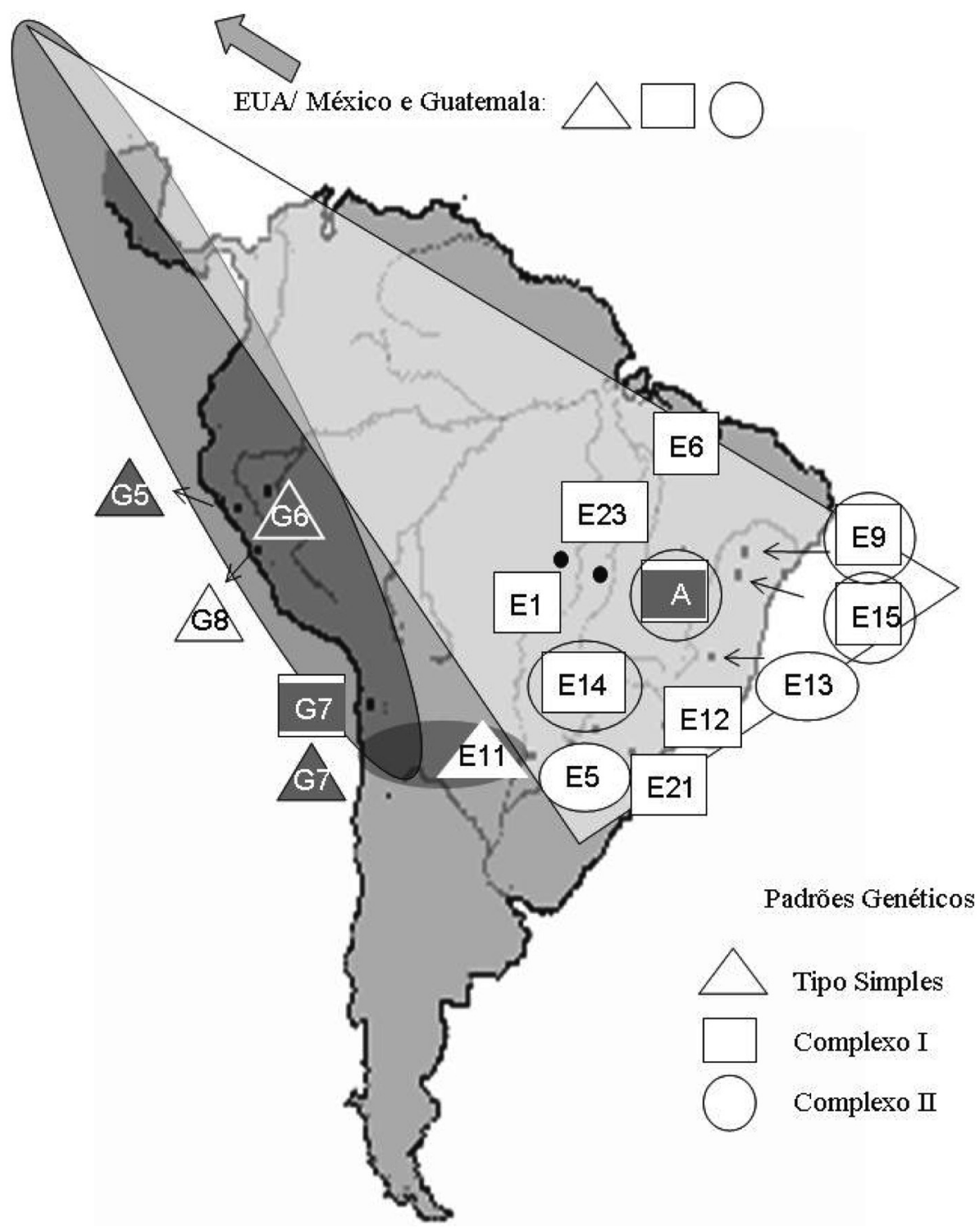

Fig. 8. Mapa com distribuição dos padrões genéticos encontrados nas amostras de milho: notese que o tipo simples aparece mais restrito à região Andina, enquanto os dois complexos aparecem na região das terras baixas da América do Sul, sugerindo duas levas introdutórias de padrões genéticos distintos. A primeira leva tendo ocorrido por volta de 5.000 anos atrás, trazendo variedades do grupo genético tipo simples e, a outra, trazendo os dois complexos, provavelmente ocorreu a partir de 2.000 anos atrás (figura adaptada de Freitas 2002).

deixadas pelos pré-históricos contêm agora muitos restos alimentares, pequenos mamiferos, peixes, gastrópodes, além de restos vegetais, de plantas não domesticadas.

Além disso, no sítio Russinho, margem do rio São Francisco, aparece uma cerâmica diferente daquelas encontradas no Cânion. A montante do cânion, no setor denominado Zona de Transição, em superfície, aparecem peças bifaciais misturadas à cerâmica Tupi, confirmando assim a tendência observada dentro do cânion. 
O que ocorreu nos últimos 2000 anos no vale do Peruaçu? Uma análise multidisciplinar para abordar os padrões culturais e suas mudanças entre as populações humanas daquela região.

Revista do Museu de Arqueologia e Etnologia, São Paulo, 20: 109-126, 2010.
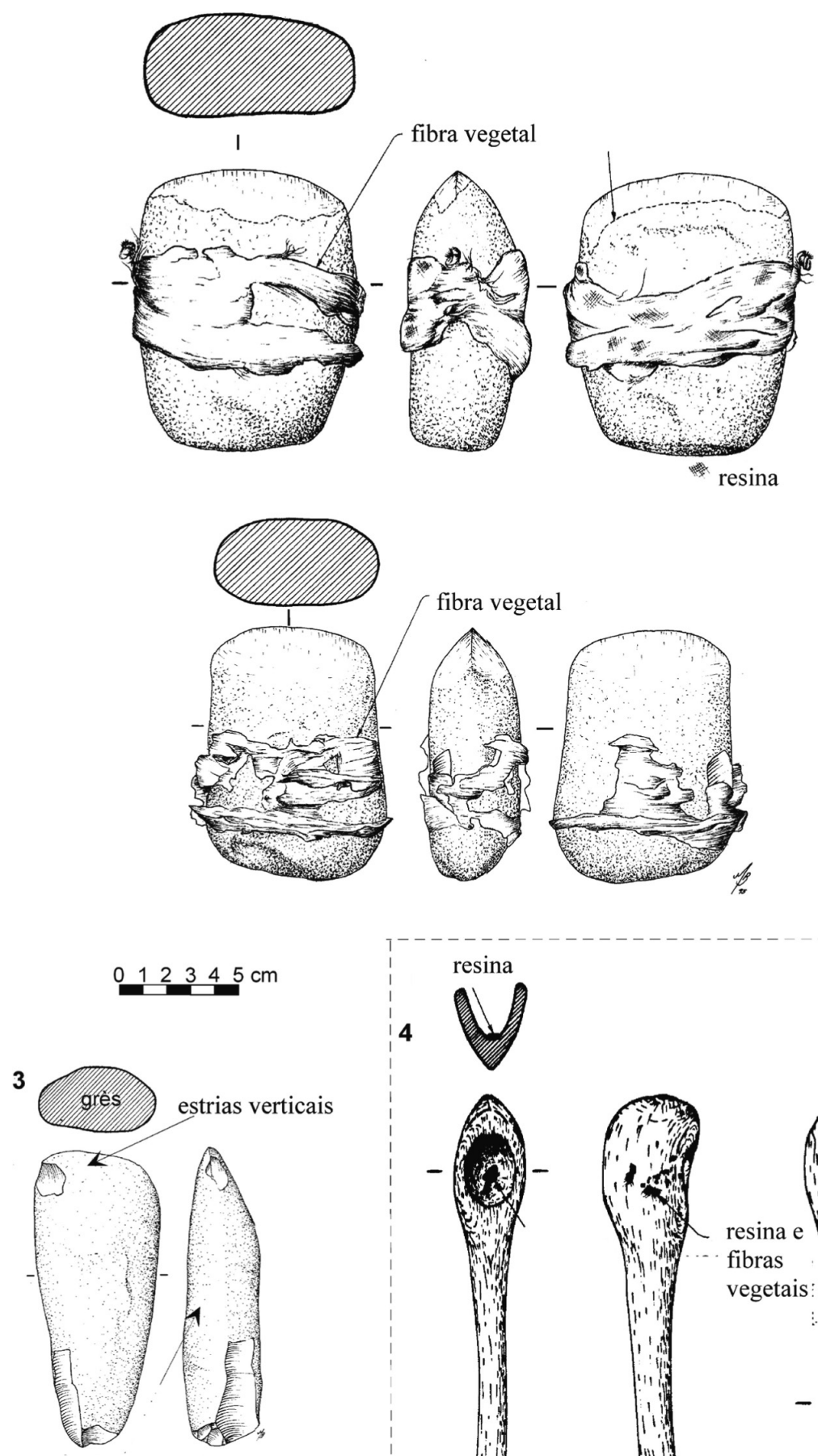

lâmina em quartzito

Fig. 9. Lâminas de machados polidas encontrados nos sepultamentos (desenho: M. Brito,

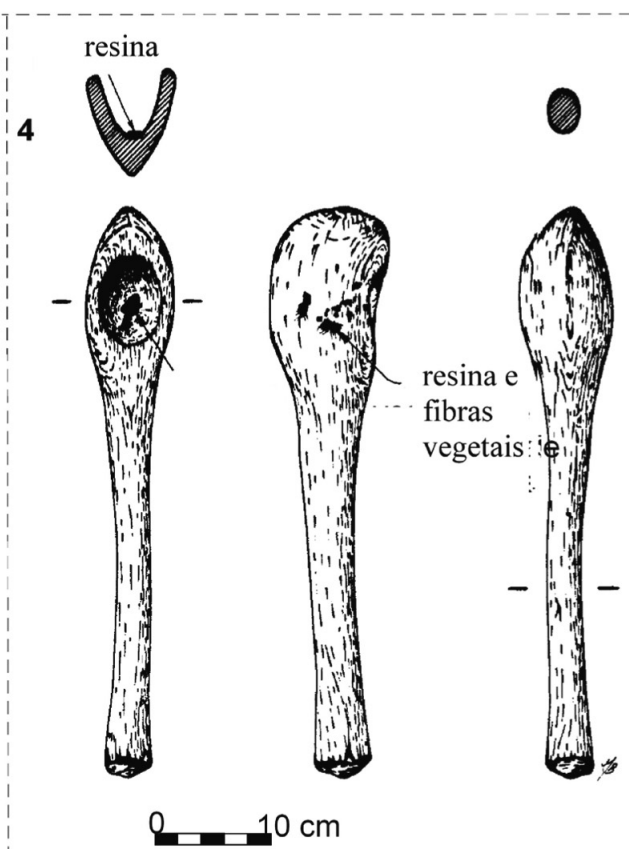
adaptado em M.J. Rodet 2006). 
De fato, quatro elementos tecnológicos apareceram ao mesmo tempo nos abrigos e nos sítios a céu aberto da bacia do rio Peruaçu, são eles: as lâminas de machado polidas, os instrumentos lascados bifacialmente, a cerâmica Tupi e as pontas de projétil bifaciais. Para completar o quadro, aparece o milho geneticamente diferente daqueles encontrados nos periodos anteriores.

A ocupação dos abrigos muda mais uma vez neste último periodo da ocupação. Aparecem muitas fogueiras com restos alimentares. Se até então, ao longo da estratigrafia, não havia muitos utensilios nos abrigos, neste momento, eles aparecem em maior número em superfície, tanto nos sítios a céu aberto, quanto nos abrigos: é como se o cânion e a zona de transição estivem mais povoados do que antes e por grupos até então não presentes, pois trouxeram com eles novas tecnologias, como a cerâmica pintada ou os bifaciais lascados, além de um novo tipo de milho.

\section{Considerações finais}

O conjunto de dados apresentados aponta para uma modificação no comportamento dos grupos a partir de $2.000 \mathrm{AP}$ até o Contato. Ao longo do periodo de ocupação pré-histórica, os abrigos parecem tomar pouco a pouco um lugar no imaginário dessas sociedades. De simples locais de paradas, os mesmos tomam uma dimensão cerimonial. Dentro desse contexto, os cestos com seus restos de vegetais podem ser vistos não como locais de armazenamento de alimento, mas como oferendas. Os abrigos seriam locais sagrados, aptos a receberem corpos, pinturas etc. Seriam os cestos oferendas por um ano rico em alimento? De todo modo, essas são questões dificeis a serem respondidas. $\mathrm{O}$ que nossas pesquisas podem afirmar é que tais estruturas, os cestos, em todo caso, aqueles exumados dos abrigos do norte do estado, não foram utilizados para guardar alimentos utilizados posteriormente para plantio ou consumo.

Outro ponto interessante dessa pesquisa aponta para o fato de que no periodo em que as populações ceramistas-horticultoras se instalam na bacia do Peruaçu, notam-se no registro arqueológico novidades em diferentes dimensões dessa sociedade - novas tecnologias de tratamento da argila, que vão gerar a produção cerâmica, novas produções nas indústrias liticas, que vão gerar instrumentos diferentes daqueles produzidos até então e produção de alimentos, através da horticultura. Esse aspecto é interessante, pois muitas vezes os arqueólogos só conseguem perceber modificação em um aspecto da vida dos grupos passados quando, de fato, a transformação de um elemento tecnológico vem, em geral, acompanhada de outras transformações. Nesse caso, conseguimos demonstrar que a partir de certo periodo, no norte do estado de Minas Gerais, aconteceram modificações em diferentes setores da vida desses grupos. Essas estão ligadas, certamente, às novas tecnologias inventadas, adaptadas ou adquiridas e também, às necessidades que as mesmas engendraram. É possivel que um instrumental cerâmico novo necessite de novos utensílios líticos e, ao mesmo tempo, leve ao abandono de outros, que se tornam obsoletos, por exemplo. Assim como o fato de produzir alimentos pode ter gerado no imaginário dessas pessoas outras necessidades que abarcam novos comportamentos e dai as oferendas em forma de cestos.

De toda maneira, nota-se nos abrigos uma grande transformação que vem se construindo ao longo dos periodos, desde o inicio da ocupação dos mesmos, mas que "explode" durante esse periodo ceramista-horticultor. Acreditamos que houve neste momento uma grande modificação mental dos grupos, pelo menos é o que podem indicar transformações dessa natureza ou dessas dimensões, ou seja, transformar a argila através do fogo e produzir seu próprio alimento (pelo menos em parte, pois os grupos não deixam de coletar) são escolhas dos nossos ancestrais que, certamente, estão ligadas às suas necessidades intelectuais, mais do que suas necessidades físicas. Pois, como dissemos ao longo dessas páginas, produzir alimento é algo difícil e os Homens que frequentavam a região norte do atual estado de Minas Gerais estavam muito bem 
instalados e havia alimentos, vegetais e caça, em abundância na região, ou seja, essa transformação em seus hábitos não foi uma necessidade, mas uma escolha.

Enfim, a última ocupação (superfície) ilustra também uma modificação impressionante na maneira de frequentar os abrigos. Se até então os abrigos nunca livraram muitos utensílios - a indústria litica sempre foi representada pelas fases finais de confecção dos mesmos: façonage e retoque - durante esta última fase, os utensilios tornam-se numerosos, em todo caso para alguns abrigos, mas também para os sitios a céu aberto em geral. $\mathrm{O}$ número de fogueiras aumenta e os restos encontrados se diversificam. Esse momento pode estar relacionado com a chegada dos bandeirantes à região. Por volta de 1.694 d.C., Matias Cardoso, se instala na foz do rio das Velhas e faz, durante sete anos, o que foi denominado "guerra aos bárbaros" e praticamente extermina os indios da região (Puntoni 2001; Santos 2004). É possivel que a grande quantidade de utensilios encontrados em superfície dos sítios arqueológicos da bacia do rio Peruaçu corresponda a este momento, em que os grupos, acuados, se escondiam em locais mais dificeis de acesso, mais seguros.

Deste modo, o trabalho procurou determinar e salientar distintas fontes de características culturais das populações humanas do Vale do rio Peruaçu, ao longo de seu perfil temporal, principalmente entre o periodo de 2.000 e 500 anos atrás, a fim de embasar a construção dos cenários vivenciados no cotidiano daqueles grupos. E, a partir da análise das caracteristicas e a evolução destes conjuntos de fatores materiais, deixados pelos grupos humanos, vislumbrar e intuir parte da cultura e costumes imateriais locais.

FREITAS, F.O; RODET, M.J. What happened in the last 2000 years in the valley of Peruaçu? A multidisciplinary analysis to address the cultural patterns and their variations among human populations of that region. Revista do Museu de Arqueologia e Etnologia, São Paulo, 20: 109-126, 2010.

Abstract: We tried to determine different sources of the cultural features of prehistoric human populations who lived in the Valley Peruaçu - Minas Gerais - Brazil, along its temporal profile, since 10,000 years ago, but mainly between the period of 2000 and 500 years ago in order to base the construction of the scenarios experienced in daily life of those populations. And from the analysis of the characteristics and evolution of this set of material factors, left by those populations, envision and intuit part of their culture and immaterial customs. The analysis was based on lithic tool industry; food used, mainly maize, graves; structures to "store" food; and our own data and literature on the archaeological sites in the region. So we can say that there was a major cultural change in the region between 2000 and 500 years ago, in-depth discussion in the article.

Keywords: Prehistoric culture - Maize - Lithic tradition - Cultural dynamics. 


\section{Referências bibliográficas}

ARANTES, A.A.

1981 O que é cultura popular. São Paulo: Brasiliense.

HAMZE, A.

2005 Artigo acessado em 6 de julho, no endereço http://www.pedagogia.brasilescola.com/ cultura-educacao.php

CARDOSO, J.S.; RESENDE, E.M.T.P.

1997 Vestigios vegetais. Relatório de pesquisas arqueológicas do alto médio São Francisco. Relatório parcial FINEP. Belo Horizonte: 128-135.

FOGAÇA, E.

2001 Mãos para o Pensamento - a variabilidade tecnológica de indústrias líticas de caçadorescoletores holocênicos a partir de um estudo de caso: as camadas VIII e VII da Lapa do Boquete (Minas Gerias, Brasil - 12000/ 10500 B.P.). Tese de Doutorado, PUC, Porto Alegre.

FREITAS, F.O.

2001 Estudo genético evolutivo de amostras modernas e arqueológicas de milho (Zea mays mays, L.) e feijão (Phaseolus vulgaris, L.). Tese de Doutorado, ESALQ/ USP, Piracicaba.

2002 As expansões do milho - Zea mays mays, 1. para a América do Sul, baseado no resgate e estudo de DNA ancião de amostras arqueológicas. Boletim de Pesquisa Embrapa, 32: 1-19.

2003 Áreas de contato de populações préhistóricas, observado através do resgate de DNA de amostras arqueológicas de milho - Zea mays, L. Revista de arqueologia, 16: 47-57.

FREITAS, F.O.; BANDEL, G.; ALLABY, R. G.; BROWN, T.A.

2003 DNA from primitive maize landraces and archaeological remains: implication for the domestication of maize and its expansion into South America. Journal of Archaeological Science, 30: 901-908.

JOBIM, P.

1997 A cerâmica do vale do rio Peruaçu, metodologia de análise. Relatório parcial FINEP. Belo Horizonte: 10 p.

JUNQUEIRA P.; MALTA, I.

1981/82 Horticultores e ceramistas pré-historicos no noroeste de Minas Gerais. Arquivos do MHN-UFMG, 6/7: 275-287.

PROUS; A.

1991a Fouilles de l'Abri du Boquete, Minas
Gerais, Brésil. Journal de la Société des Américanistes, LXXVII: 77-109.

1991b Arqueologia do vale do Rio Peruaçu. Belo Horizonte: MHN-UFMG.

1994 a Notas sobre algumas estruturas arqueoló gicas do periodo ceramista. In: Estudo arqueológico do vale do rio Peruaçu, Januária / Itacarambi - MG, Belo Horizonte, MHN-UFMG/ FAPEMIG 1992/1993: 97-107.

1994 b A cerâmica da Lapa do Boquete. In: Estudo arqueológico do vale do rio Peruaçu, Januária / Itacarambi - MG, Belo Horizonte, MHN-UFMG/FAPEMIG 1992/1993: 109-114.

PROUS, A. ; ALONSO, M. ; FOGAC̣A, E. ; BRITO, M.

1992 A indústria litica da camada VIII da Lapa do Boquete. Vale do rio Peruaçu, MG (Brasil). Anais do III Congresso da Associação Brasileira de Estudos do Quaternário, 3: 330-386.

PUNTONI, P.

2002 A Guerra dos Bárbaros: Povos Indígenas e a colonização do Sertão Nordeste do Brasil, 1650-1720. São Paulo: Hucitec, Editora da Universidade de São Paulo, Fapesp.

RELATÓRIO FNMA

1997 Arqueologia do vale do rio Peruaçu, Januaria, MG. Belo Horizonte, Museu de História Natural - UFMG.

RESENDE, E.M.T.P.

1994 Os restos vegetais. In: Estudo arqueológico do vale do rio Peruaçu, Januária / Itacarambi . MG, Belo Horizonte, MHN-UFMG/ FAPEMIG 1992/1993: 183-201.

RESENDE, E.M.T.P.; CARDOSO, J.S.

1996 Estruturas de armazenamento vegetal: os "silos" do vale do rio Peruaçu (MG). Anais da VIII Reunião Científica da Sociedade de Arqueologia Brasileira, PUCRS, 1 (2): 249-264.

1997 Alimentação dos Homens pré-históricos: restos vegetais. Relatório final FNMA: Arqueologia do vale do rio Peruaçu/ Januária - MG. Belo Horizonte: 51-57.

2009 Vestigios Vegetais: arqueobotânica e técnicas tradicionais de armazenamento. Arquivos do Museu de Historia Natural, XIX, UFMG: 231-260.

RODET, M.J.

2006 Etude technologique des industries lithiques taillées du nord de Minas Gerais - Brésil, depuis le passage Pléistocène/Holocène jusqu'au contact - XVIII ème siècle. Tese de 
O que ocorreu nos últimos 2000 anos no vale do Peruaçu? Uma análise multidisciplinar para abordar os padrões culturais e suas mudanças entre as populações humanas daquela região.

Revista do Museu de Arqueologia e Etnologia, São Paulo, 20: 109-126, 2010.

Doutorado, Université de Paris X, Paris. 516p.

2009 O estudo tecnológico das indústrias liticas da bacia do rio Peruaçu: cadeias operatórias, métodos de debitagens, técnicas de lascamento. Arquivos do Musen de Historia Natural, UFMG: 277-287.

RODET, M.J. ; RODET, J.; HORN, A.H.

2008 Système géomorphologique et système antrhopique préhistorique au Brésil. Exemple de l'état de Minas Gerais. Anais $6^{\circ}$ Sinageo - Simpósio Nacional de Geomorfologia, Belo Horizonte, CD. SANTOS, M.

2004 Bandeirantes paulistas no sertão do São Francisco - Povoamento e expansão pecuária de 1688 a 1734 . Versão adaptada da dissertação de mestrado, Belo Horizonte, UFMG. 